\title{
Upper Midwest Environmental Sciences Center
}

\section{Who We Are}

The Upper Midwest Environmental Sciences Center (Center) is 1 of 18 U.S. Geological Survey (USGS) biological research and technology centers throughout the United States. These centers are the research arm of the U.S. Department of the Interior (DOI) and provide science information for the U.S. Fish and Wildlife Service, the U.S. Park Service, the Bureau of Land Management, and other DOI agencies.

\section{The Facility}

The Center is situated on 65 acres of Federal land that houses a 70,000 square-foot USGS-owned research facility with stateof-the-art laboratories and almost 50 experimental ponds and raceways. The Center also includes sophisticated waterhandling and treatment facilities, which allows us to work on a wide variety of fish and wildlife species, as well as contaminants affecting the environment.

We cooperate with the states of Illinois, Iowa, Minnesota, Missouri, and Wisconsin to manage six field stations. These stations are a critical part of the Long Term Resource Monitoring Program (LTRMP), the Nation's largest river inventory,



destroy undesirable fish (carp, sheepshead, sea lamprey) in fresh waters. A new facility was built in 1978 on French Island, and research activities expanded to include ecology of large rivers and fish and wildlife studies. River research continued to expand in the mid-1980s with the creation of the LTRMP. The present Center program is diverse, with research conducted in over 20 states and Canada. monitoring, and science program. Nearly 200 people work at the Center and field stations.

\section{Our History}

The Center began in 1959 as the Fish Control Laboratory in a remodeled fish hatchery in Riverside Park, La Crosse, Wisconsin. The laboratory was nationally responsible for developing chemical agents to

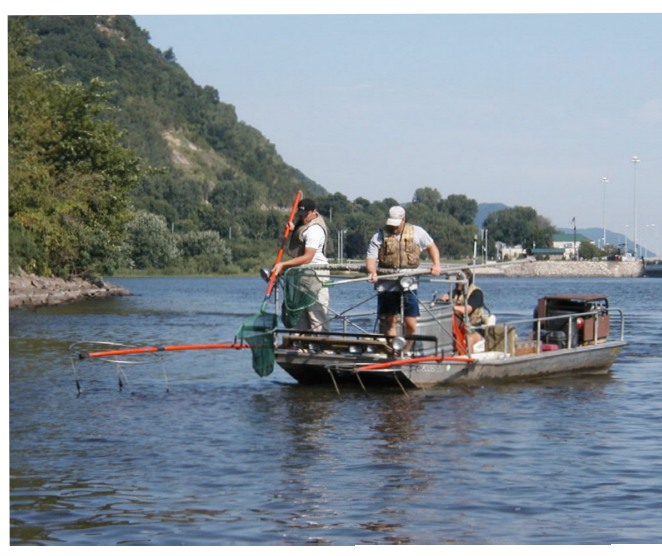




\section{Our Studies}

Our studies are in five important areas:

- Studying the population and ecosystem effects of invasive, non-native species in the Upper Mississippi River and Great Lakes Basins;

- Examining and monitoring the status of the Upper Mississippi River System;

A Investigating declining species in the Midwest: amphibians, mussels, large river fishes, and migratory birds;

^ Developing computer-generated habitat needs and decision support systems to assist managers in making decisions; and

$\lambda$ Documenting the effects of chemicals and drugs used in public fish hatcheries.

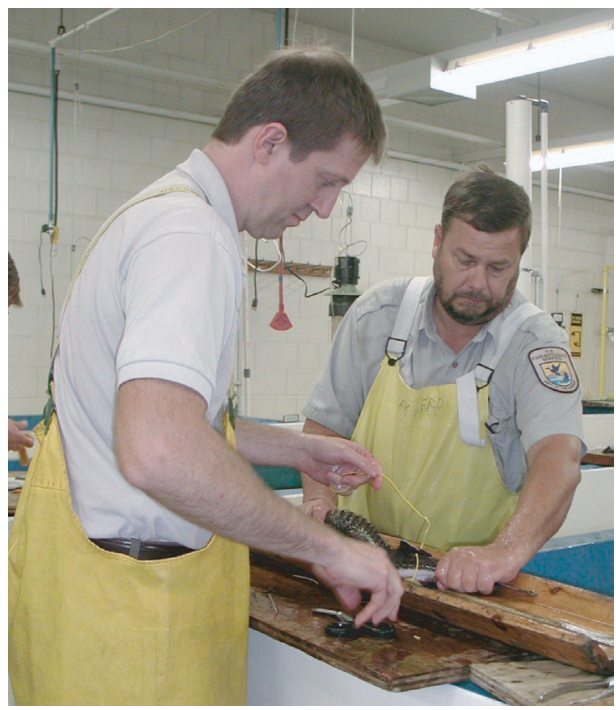

\section{Our Partners}

We have many partners who use our research in their efforts. In addition to other DOI agencies, we provide information to the Great Lakes Fishery Commission, International Association of Fish and Wildlife Agencies, U.S. Army Corps of Engineers, Canadian resource agencies, U.S. Environmental Protection Agency, Natural Resources Conservation Service, and numerous states and universities.

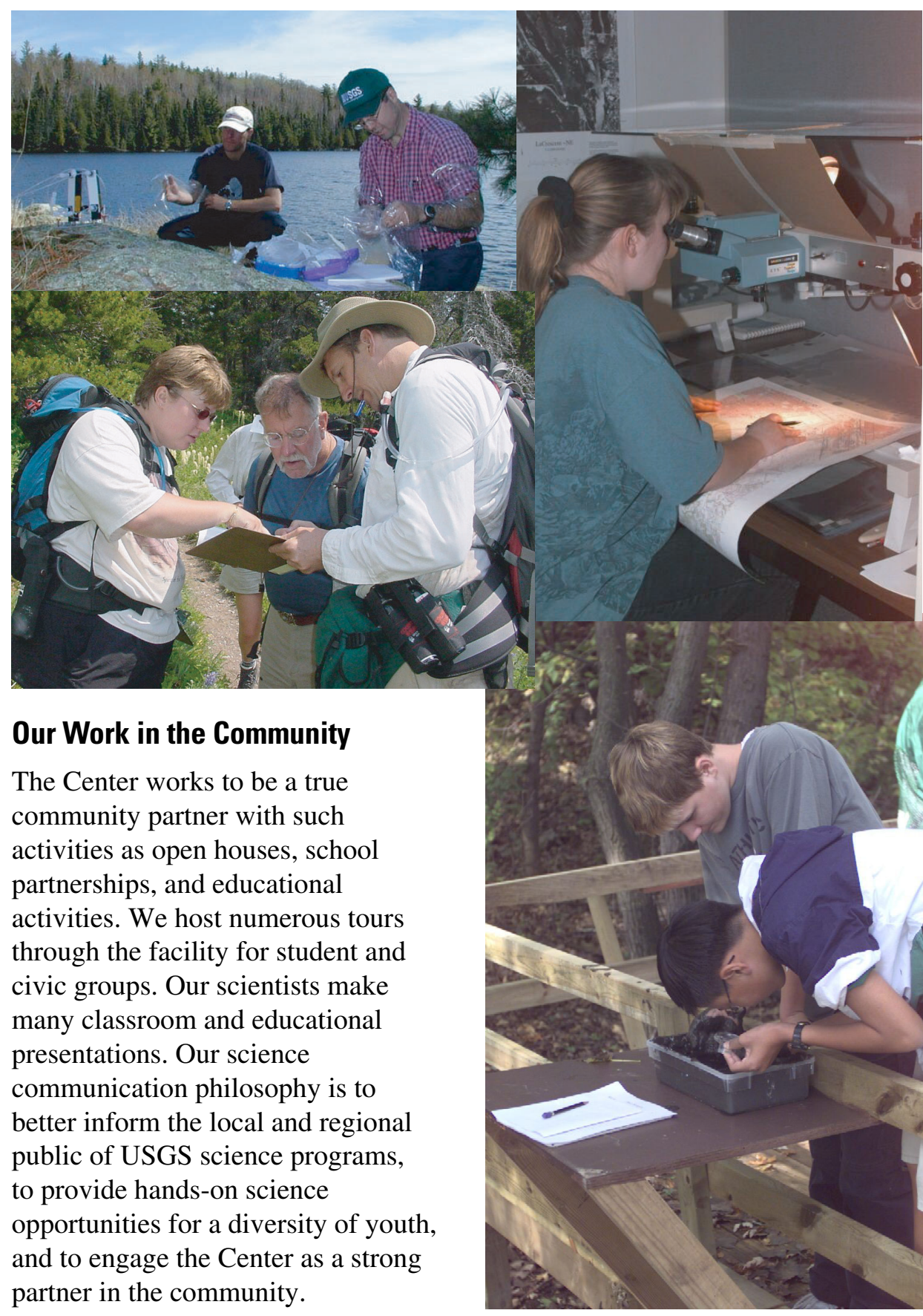

\section{For more information, contact-}

Randy Hines

USGS Upper Midwest Environmental Sciences Center

2630 Fanta Reed Road

La Crosse, WI 54603

Phone: 608.781 .6398

Email: rkhines@usgs.gov

http://www.umesc.usgs.gov/

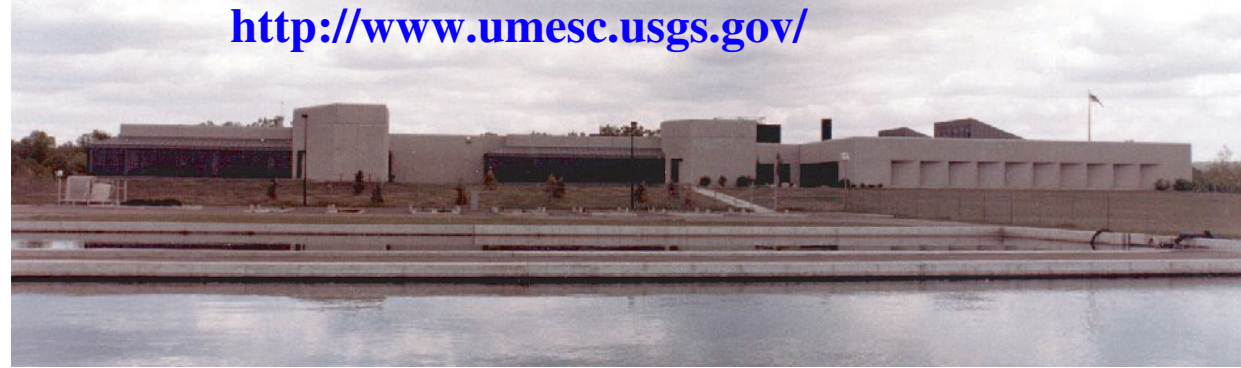

